\title{
MENINGKATKAN KEMAMPUAN BERPIKIR KREATIF DAN PEMECAHAN MASALAH MATEMATIS SISWA MADRASAH
}

\section{ALIYAH}

\author{
Wawan Kusmawan ', Turmudi', Dadang Juandi ${ }^{2}$ dan Hamdan Sugilar3 \\ 'MAN 2 Kota Bandung \\ ${ }^{2}$ Departemen Pendidikan Matematika, Universitas Pendidikan Indonesia \\ 3Prodi Pendidikan Matematika, UIN Sunan Gunung Djati Bandung \\ E-mail:wkusmawan21@yahoo.com
}

\begin{abstract}
ABSTRAK
Tujuan penelitian ini untuk mengkaji perbedaan peningkatan kemampuan berpikir kreatif dan pemecahan masalah antara siswa yang mendapatkan pembelajaran model investigasi kelompok dengan siswa yang mendapatkan pembelajaran biasa. Subjek penelitian ini adalah siswa Madrasah Aliyah dengan sampel penelitian terdiri dari dua kelas yang diambil secara acak dari delapan kelas XI yang ada di Madrasah Aliyah Negeri 2 Kota Bandung dengan teknik purposive sampling. Kelas pertama sebagai kelas kontrol dan kelas kedua sebagai kelas eksperimen. Kelas kontrol memperoleh pembelajaran biasa dan kelas eksperimen memperoleh pembelajaran dengan model investigasi kelompok. Pengumpulan data hasil penelitian menggunakan instrumen berupa soal-soal tes kemampuan berpikir kreatif dan pemecahan masalah matematis dianalisis secara kuantitatif. Data sebelum dianalisis terlebih dahulu diuji normalitas dan homogenitas dilanjutkan uji-t, jika data tidak normal memakai uji Mann-Whitney. Data hasil skala sikap dianalisis secara kualitatif. Hasil penelitian ini menunjukkan bahwa adanya perbedaan peningkatan kemampuan berpikir kreatif dan pemecahan masalah matematis antara siswa yang menggunakan pembelajaran model investigasi kelompok dengan siswa yang menggunakan pembelajaran biasa. Analisis data angket skala sikap memperlihatkan bahwa siswa bersikap positif terhadap pembelajaran matematika yang mencakup sikap terhadap pelajaran matematika, pembelajaran dengan model investigasi kelompok maupun terhadap soal-soal kemampuan berpikir kreatif dan pemecahan masalah matematis.
\end{abstract}

Kata kunci: model investigasi kelompok, berpikir kreatif, pemecahan masalah matematis

\section{IMPROVING CREATIVE THINKING ABILITY AND PROBLEM SOLVING OF STUDENTS MATHEMATICS MADRASAH ALIYAH}

This study aimed to assess the differences increased ability to think creatively and problem solving among students who have learnt math using investigation group models and students who get regular learning. The subject of this study were students of Madrasah Aliyah with the study sample was composed of two classes taken randomly from the eight classes of grade XI at Madrasah Aliyah Negeri 2 Bandung with a purposive sampling technique. The first class is considered as the control class and second one class as a experiment class. Regular classroom as a control group where as the experiment class was the class who learnt by using group investigasi model. This study uses data collection instrument using mathematical test to measure the in creative thinking ability and their problem solving ability. Before the data are analyzed, it must be tested the normality and homogeneity of the t-test. If the data is not normal it should use Mann-Whitney test. The attitude scale data were analyzed qualitatively. The results of the research is indicated that there were differences increating students thinking creativity and also problem solving of mathematics among student who use learning model investigation group with who use ordinary learning. Attitude scale questionnaire data analysis showed that student attitudes toward learning mathematics positively learning throught model investigation group not only increased student thinking creativity but also to student problem solving of mathematics it self.

Keywords: investigation group model, creative thinking ability, problem-solving mathematics 


\section{PENDAHULUAN}

Kurang berhasilnya pembelajaran matematika dapat disebabkan beberapa faktor, diantaranya adalah faktor kemampuan guru dalam menerapkan metode, kurang melibatkan siswa aktif pada pembelajaran, atau strategi pembelajaran yang kurang tepat (Sugilar, 2013). Proses pembelajaran cenderung berpusat pada guru, siswa cenderung pasif. Bahkan Wahyudin (1999:6) menegaskan bahwa guru matematika pada umumnya mengajar dengan metode ceramah dan ekspositori. Sehingga siswa tidak mempunyai kesempatan untuk mengembangkan kemampuan berpikir matematis.

Matematika sendiri banyak dipandang mengajarkan hal yang tidak kreatif, kaku dan memaksa pola yang sudah baku. Penyelesaian masalah matematika dianggap tunggal tidak memberi ruang pada perbedaan jawaban atau cara yang berbeda. Pembelajaran matematika masih cenderung pada konsep tradisional, yakni hanya menjejalkan rumus-rumus dan hafalan tanpa memberi masukan bagaimana siswa menyelesaikan suatu permasalahan dengan baik, sehingga siswa kurang diberi kesempatan untuk mengembangkan kreativitas dan produkvitasnya. Ditegaskan pula oleh Sabandar (2009) bahwa terdapat perubahan pandangan mengenai tujuan pendidikan bahwa kemampuan berpikir harus menjadi tujuan yang penting dan utama dalam proses pembelajaran.

Dari berbagai permasalahan itu, pembelajaran matematika mengalami perubahan pandangan. Matematika yang dulu diberikan dengan pola yang cenderung siswa untuk menghapal dan menyelesaikan soal-soal berdasarkan contoh. Saat ini pembelajaran matematika harus diberikan pada siswa mengacu pada berbagai kemampuan yang dicapai. Meningkatkan kemampuan berpikir kreatif siswa menjadi tujuan utama dalam pembelajaran matematika. Berpikir kreatif matematis memunculkan kegiatan yang sarat kreativitas dalam pembelajaran matematika. Kreativitas merupakan produk dari berpikir kreatif. Aktivitas kreatif merupakan aktivitas yang diarahkan untuk mendorong siswa memunculkan kreativitasnya.Kemampuan berpikir kreatif mempunyai hubungan yang sangat kuat dengan kemampuan pemecahan masalah. Seseorang yang mempunyai kemampuan berpikir kreatif tidak hanya mampu memecahkan masalah-masalah non rutin, tetapi juga mampu melihat berbagai alternatif dari pemecahan masalah itu. Kemampuan berpikir kreatif merupakan bagian yang sangat penting untuk kesuksesan dalam pemecahan masalah.

Kemampuan untuk memecahkan masalah merupakan kemampuan yang penting dimiliki siswa bahkan sebagai jantung dari pembelajaran matematika (Susilawati,dkk, 2017). Terdapat beberapa kompetensi yang perlu dikaji dalam pendidikan matematika, salah satu diantaranya adalah kemampuan pemecahan masalah. Menurut Sovhick (dalam Haji, 2004), bahwa latihan pemecahan masalah akan dapat menghasilkan individu-individu yang kompeten dalam bidang matematika, karena memiliki manfaat yang besar bagi penanaman kompetensi matematika siswa. Turmudi (2009) menegaskan dengan menggunakan pemecahan masalah siswa mengenal cara berpikir, kebiasaan untuk tekun, keingintahuan yang tinggi, serta percaya diri dalam situasi yang tidak biasa, yang akan melayani mereka (para siswa) secara baik di luar kelas matematika. 
Meningkatkan Kemampuan Berpikir Kreatif dan Pemecahan Masalah Matematis Siswa Madrasah Aliyah

Kemampuan berpikir kreatif dan pemecahan masalah sarat dengan soal-soal terbuka. Dengan soal seperti itu siswa banyak yang mengalami kesulitan menjawabnya.Melihat tingkat kesulitannya pemecahan masalah lebih baik dilaksanakan secara kelompok. Dengan kelompok siswa memungkinkan mereka untuk saling tukar ide dan memperdebatkan alternatif pemecahan masalah yang bisa digunakan. Lebih baik jika kelompok itu dibentuk dalam jumlah kecil karena siswa lebih efektif bekerja sama dan saling tukar pikiran sesamanya tentang masalah yang dihadapi. Sumarmo (2005: 3) juga menyarankan pembelajaran matematika yang mendorong berpikir kreatif dan berpikir tingkat tinggi antara lain dapat dilakukan melalui belajar pada kelompok kecil, tugas non rutin atau tugas yang menuntut strategi kognitif dan metakognitif peserta didik serta menerapkan pendekatan scaffolding. Lebih baik jika kelompok itu dibentuk dalam jumlah kecil karena siswa lebih efektif bekerja sama dan saling tukar pikiran sesamanya tentang masalah yang dihadapi.

Di sekolah proses pembelajaran matematika masih dilaksanakan secara biasa, artinya belum diarahkan guru pada pembelajaran ideal dengan memanfaatkan wewenangnya sebagai pengembang strategi pembelajaran di kelas. Siswa Sekolah Menengah Atas cenderung mengalami kesulitan dalam belajar matematika, khususnya dalam menyelesaikan soal yang berhubungan dengan kemampuan pemecahan masalah matematik sebagaimana diungkapkan Sumarmo (1993) bahwa kemampuan siswa SMA kelas I dalam menyelesaikan masalah matematika pada umumnya belum memuaskan.

Jurnal Analisa Vol.4 No.1 Juni 2018: 33-42
Model Investigasi Kelompok dapat melatih siswa untuk menumbuhkan kemampuan berfikir mandiri. Dalam pembelajaran dengan menggunakan model investigasi siswa dituntut untuk lebih aktif dalam mengembangkan sikap dan pengetahuannya tentang matematika, sesuai dengan kemampuan masing-masing, sehingga dapat memberikan hasil belajar yang lebih bermakna pada siswa. Keterlibatan siswa secara aktif dapat terlihat mulai dari tahap pertama sampai tahap akhir pembelajaran.

Investigasi kelompok merupakan salah satu bentuk model pembelajaran kooperatif yang menekankan pada partisipasi dan aktivitas siswa untuk mencari sendiri materi atau informasi pelajaran yang akan dipelajari melalui bahan-bahan yang tersedia, misalnya dari buku pelajaran atau siswa dapat mencari melalui internet. Peningkatan cara belajar siswa tersebut dapat dilihat dari antusias dan kerjasamanya dalam belajar kelompok.

Untuk menghindari meluasnya permasalahan yang akan dikaji dalam penelitian ini, masalah penelitian dibatasi dengan pembatasan subyek penelitian adalah siswa Madrasah Aliyah (MA), Konsep yang diteliti dibatasi pada konsep aplikasi turunan. Tujuan yang telah dicapai dalam penelitian ini adalah sebagai berikut:

Hasil kajian perbedaan peningkatan kemampuan berpikir kreatif dan pemecahan masalah matematis antara siswa yang menggunakan pembelajaran model investigasi kelompok dengan siswa yang memperoleh pembelajaran biasa, hasil kajian perbedaan peningkatan kemampuan berpikir kreatif dan pemecahan masalah matematis siswa yang kemampuan matematika tinggi, sedang dan rendah pada 
siswa yang menggunakan pembelajaran model investigasi kelompok dengan siswa yang memperoleh pembelajaran biasa.

Model investigasi kelompok dapat melatih siswa untuk menumbuhkan kemampuan berfikir mandiri. Dalam pembelajaran dengan menggunakan model investigasi siswa dituntut untuk lebih aktif dalam mengembangkan sikap dan pengetahuannya tentang matematika, sesuai dengan kemampuan masing-masing, sehingga dapat memberikan hasil belajar yang lebih bermakna pada siswa. Keterlibatan siswa secara aktif dapat terlihat mulai dari tahap pertama sampai tahap akhir pembelajaran.

\section{METODE PENELITIAN}

Penentuan sampel pada penelitian ini tidak memungkinkan untuk dilakukan acak murni. Karena itu sampling yang mungkin dilakukan adalah purposive sampling, sampel dipilih secara sengaja dengan pertimbangan tertentu (Sugiyono, 2008). Pemilihan kelas kontrol dan eksperimen berdasarkan pengundian dari delapan kelas yang setara dan tidak ada program kelas unggulan. Beberapa kegiatan yang dilaksanakan dalam rangka persiapan pelaksanaan penelitian, diantaranya: Mengidentifikasi permasalahan dan melakukan studi kepustakaan tentang pembelajaran matematika dengan model investigasi kelompok, kemampuan berpikir kreatif dan kemampuan pemecahan masalah. Menyusun instrumen tes, membuat rencana pembelajaran, merancang bahan ajar berupa LKS. Mengurus perijinan untuk melaksanakan penelitian di MAN 2 Kota Bandung sekaligus. Melakukan uji coba instrumen, pada kelas XII IPA 3 dilanjutkan dengan menganalisis validitas, realibilitas, tingkat kesukaran dan daya pembeda instrumen berupa soal dan melakukan revisi untuk digunakan dalam penelitian. Memilih sampel kelas secara acak dari delapan kelas XI yang dijadikan kelas kontrol dan eksperimen. Menyusun perangkat pembelajaran melalui persetujuan pembimbing.

Tahap awal pelaksanaan dimulai dengan pengadakan pretes pada kelas kontrol dan kelas eksperimen. Mengelompokkan siswa pada kelas eksperimen yang akan diberikan pembelajaran melalui investigasi kelompok yang terdiri dari 5-6 orang tiap kelompoknya. Melaksanakan pembelajaran dengan model investigasi grup pada kelas eksperimen dan pembelajaran biasa pada kelas kontrol. Lembar Kerja Siswa diberikan hanya pada kelas eksperimen. Setelah pembelajaran dengan materi aplikasi turunan selesai diberikan sebanyak 6 kali pertemuan. Kelas kontrol dan kelas eksperimen diberikan postes berupa soal kemampuan berpikir kreatif dan pemecahan masalah matematis. Soal-soal postes merupakan soal yang sama diberikan pada saat pretes. Pelaksanaan tes kemampuan berpikir kreatif dan pemecahan masalah masing-masing 60 menit tiap kemampuan. Setelah postes berakhir dilanjutkan siswa kelas ekperimen mengisi angket skala sikap.

Data yang diperoleh dari hasil pretes dan postes dianalisis secara statistik sedangkan observasi dianalisis secara deskriptif. Pengolahan data kuantitatif menggunakan bantuan program komputer softward SPSS versi 20. Uji normalitas ini menggunakan uji statistik Kolmogorov-Smirnov dengan kriteria pengujian, jika nilai signifikansi $>\alpha$. Uji homogenitas adalah pengujian mengenai sama tidaknya variansi-variansi dua buah distribusi (Ruseffendi, 1993:373). Untuk mengetahui distribusi data tersebut 
Meningkatkan Kemampuan Berpikir Kreatif dan

homogen atau tidak, digunakanlah uji Homogeneity of Variances (Levene Statistic). Uji statistiknya menggunakan Uji Levene dengan kriteria pengujian yaitu $\mathrm{H}_{\mathrm{o}}$ diterima apabila nilai signifikansi $>$ taraf signifikansi. Uji perbedaan dua rata-rata yang digunakan tergantung dari hasil uji normalitas dan uji homogenitas variansi data. Jika kedua data berdistribusi normal, dan variansi kedua kelompok data homogen, uji perbedaan dua rata-rata menggunakan uji statistik parametrik, yaitu uji Independent-Samples T Test (Uji-t). Selanjutnya, jika terdapat minimal satu data yang tidak berdistribusi normal, maka uji perbedaan dua rata-rata menggunakan uji statistik nonparametrik, yaitu Uji MannWhitney karena dua sampel yang diuji saling bebas/independen (Ruseffendi, 1993).

Teknik pengaturan kelompok siswa berdasarkan kemampuan awal matematika diperoleh melalui hasil tiga kali tes sebelum penelitian dilaksanakan. Urutan kemampuan siswa pada kelas kontrol dan kelas eksperimen disusun dari perolehan skor tertinggi ke terendah. Susunan itu diambil $27 \%$ dari jumlah siswa masingmasing kelas dari atas untuk kemampuan tinggi, dari bawah $27 \%$ untuk kemampuan rendah dan sisanya untuk kemampuan sedang. Jumlah siswa kelompok tinggi dan rendah kelas kontrol masing-masing berjumlah 10 orang. Jumlah siswa kelompok sedang kelas kontrol berjumlah 17 orang. Jumlah siswa kelompok tinggi dan rendah untuk kelas eksperimen masingmasing berjumlah 11 orang. Jumlah siswa kelompok sedang kelas eksperimen berjumlah 17 orang. Skala sikap yang digunakan dalam penelitian ini berbentuk skala Likert memuat empat komponen. Setiap komponen memuat beberapa pertanyaan yang dilengkapi empat pilihan jawaban yaitu: Sangat Setuju (SS), Setuju
(S), Tidak Setuju (TS) dan Sangat Tidak Setuju (STS). Pada setiap pernyataan, setiap pilihan jawabannya diberi skor minimal 1 dan maksimal 4. Untuk pernyataan positif yang jawabannya sangat setuju (SS) diberi nilai 4 dan untuk pilihan jawaban lainnya, yaitu S, TS dan STS berturut-turut berbeda satu. Sebaliknya untuk pertanyaan negatif yang jawabannya sangat tidak setuju (STS) diberi nilai 4 dan untuk pilihan lainnya, yaitu TS, S, dan SS berturut-turut berbeda satu. Selanjutnya rata-rata skor skala sikap dibandingkan dengan skor netral. Skor netral pada penelitian ini sebesar 2,50.

\section{HASIL DAN PEMBAHASAN}

Rata-rata pretes kemampuan berpikir kreatif siswa kelas kontrol sebesar 4,68 sedangkan rata-rata pretes kelas eksperimen sebesar 4,33. Rata-rata postes kemempuan berpikir kreatif kelas kontrol sebesar 8,59 dan rata-rata postes kelas eksperimen sebesar 9,87. Rata-rata gain kelas kontrol sebesar 0,35 masuk ke dalam kategori kurang dan rata-rata gain kelas eksperimen sebesar 0,48 masuk ke dalam kategori sedang.

Uji Normalitas Skor Pretes Kemampuan Berpikir Kreatif berdasarkan uji statistik Kolmogorov-Smirnov. Skor pretes pada kemampuan berpikir kreatif kelas kontrol dan kelas eksperimen memiliki nilai signifikansi 0,000 dan 0,009. Nilai itu lebih kecil dari taraf signifikansi $(\alpha=0,05)$. Maka disimpulkan bahwa skor pretes kemampuan berikir kreatif siswa kelas kontrol dan kelas eksperimen tidak berdistribusi normal. Selanjutnya uji perbedaan dua rata-rata menggunakan uji nonparametrik Mann-Whitney dan diperoleh tidak ada perbedaan yang signifikan skor pretes antara siswa kelas kontrol dan kelas eksperimen kemampuan 
berpikir kreatif. Artinya siswa kelas kontrol dan kelas eksperimen memiliki kemampuan yang sama.

Peningkatan pada kemampuan berpikir kreatif kelas kontrol mempunyai nilai signifikansi 0,200 karena lebih besar dari taraf signifikansi $\alpha=0,05$. sehingga data berdistribusi normal sedangkan pada kelas eksperimen memiliki nilai signifikansi 0,044. Karena nilai itu lebih kecil dari taraf signifikansi $\alpha=0,05$ maka $\mathrm{H}_{\mathrm{o}}$ ditolak sehingga data tidak berdistribusi normal. Dengan alasan salah satu data tidak berdistribusi normal maka uji perbedaan rata-rata memakai uji non parametrik yaitu uji Mann-Whitney. Berdasarkan uji MannWhitney peningkatan kemampuan berpikir kreatif nilai signifikansi 0,005. Nilai itu lebih kecil dari taraf signifikansi $(\alpha=0,05)$. Sehingga terdapat perbedaan yang signifikan peningkatan kemampuan berpikir kreatif antara siswa kelas kontrol dan kelas eksperimen.

Uji normalitas memperlihatkan data skor pretes kemampuan berpikir kreatif berdasarkan kemampuan awal matematis pada setiap kelompok tinggi, sedang dan rendah. Kelompok tinggi kelas kontral o,000 kelas eksperimen 0,200. Kelompok sedang kelas kontral 0,003 kelas eksperimen 0,030. Kelompok rendah kelas kontral 0,155 kelas eksperimen 0,004. Mengacu pada nilai signifikansi yang dibandingkan dengan taraf signifikansi 0,05. Jika perolehan nilai signifikansi lebih dari taraf signifikansi 0,05 maka data berdistribusi normal dan sebaliknya jika nilai signifikansi kurang dari taraf signifikansi 0,05 maka data tidak berdistribusi normal. Pada kelompok kemampuan pada kelas kontrol dan eksperimen tidak ada yang kedua-duanya berdistribusi normal, karena itu masing- masing harus digunakan uji nonparametrik Berdasarkan uji Mann-Whitney skor pretes untuk siswa kelompok tinggi pada nilai signifikansi 0,574 lebih besar dari taraf signifikansi $(\alpha=0,05)$ sehingga tidak terdapat perbedaan yang signifikan skor pretes kelompok tinggi siswa kelas kontrol dan kelas eksperimen. Artinya skor pretes kelas kontrol dan kelas eksperimen siswa kelompok tinggi tidak ada perbedaan.

Uji normalitas peningkatan berdasarkan kemampuan awal matematika yaitu uji normalitas berdasarkan kelompok siswa kategori tinggi, sedang dan rendah pada kelas kontrol dan kelas eksperimen. Kelompok tinggi kelas kontral o,069 kelas eksperimen 0,200. Kelompok sedang kelas kontral 0,192 kelas eksperimen 0,200. Kelompok rendah kelas kontral o,o8o kelas eksperimen 0,200. Setelah nilai signifikansi diperoleh dibandingkan dengan taraf signifikansi. Dan seluruh nilai signifikansi yang diperoleh pada masing-masing kelompok tinggi, sedang, dan rendah pada kelas kontrol dan kelas eksperiman dari taraf signifikansi 0,05.

Hasil uji homogenitas nilai signifikansi kelompok tinggi 0,195 dan rendah 0,625 lebih besar dari taraf signifikansi 0,05 maka disimpulkan data homogen. Sedangkan untuk kelompok sedang nilai signifikansi 0,005 lebih kecil dari taraf signifikansi 0,05 maka disimpulkan tidak homogen. Uji perbedaan rata-rata pada siswa kelompok tinggi dengan hasil uji-t o,030 terdapat perbedaan peningkatan kemampuan berpikir kreatif siswa kelompok rendah antara kelas kontrol dan kelas eksperimen. kelompok sedang dengan hasil uji-t' o,055. Jadi tidak terdapat perbedaan peningkatan kemampuan berpikir kreatif antara kelas kontrol dan kelas eksperimen.dan kelompok rendah dengan hasil uji-t o,ooo 
terdapat perbedaan peningkatan kemampuan berpikir kreatif siswa kelompok rendah antara kelas kontrol dan kelas eksperimen.

\section{Temuan Kemampuan Pemecahan Masalah Matematis}

Rata-rata pretes kemampuan pemecahan masalah matematis siswa kelas kontrol sebesar 1,27 sedangkan rata-rata pretes kelas eksperimen sebesar 1,03. Rata-rata postes kemampuan pemecahan masalah matematis siswa kelas kontrol sebesar 4,16 dan rata-rata postes kelas eksperimen sebesar 5,67. Rata-rata gain kelas kontrol sebesar 0,27 masuk ke dalam kategori kurang dan rata-rata gain kelas eksperimen sebesar 0,42 masuk ke dalam kategori sedang. Dengan demikian rata-rata postes dan gain pada kelas eksperimen lebih baik dibandingkan dengan kelas kontrol.

Uji normalitas skor pretes pada kemampuan pemecahan masalah matematis kelas kontrol memiliki nilai signifikansi 0,000 dan kelas eksperimen memiliki nilai signifikansi o,ooo. Karena nilai masing-masing itu lebih kecil dari taraf signifikansi $(\alpha=0,05)$ maka disimpulkan bahwa skor pretes kemampuan pemecahan masalah matematis siswa kelas kontrol dan kelas eksperimen tidak berdistribusi normal. Selajutnya uji Mann-Whitney skor pretes kemampuan pemecahan masalah diperoleh nilai signifikansi 0,077 nilai itu lebih besar dari taraf signifikansi $(\alpha=0,05)$ sehingga tidak ada perbedaan yang signifikan skor pretes antara siswa kelas kontrol dan kelas eksperimen kemampuan pemecahan masalah. Artinya siswa kelas kontrol dan kelas eksperimen memiliki kemampuan yang sama.

Jurnal Analisa Vol.4 No.1 Juni 2018: 33-42
Uji normalitas N-Gain pada kemampuan pemecahan masalah kelas kontrol mempunyai nilai signifikansi o,031, nilai itu lebih kecil dari taraf signifikansi $(\alpha=0,05)$ maka disimpulkan bahwa skor pretes kemampuan pemecahan masalah matematis siswa kelas kontrol tidak berdistribusi normal. Pada kelas eksperimen memiliki nilai signifikansi 0,200, nilai itu lebih besar dari taraf signifikansi $(\alpha=0,05)$ maka data kelas eksperimen berdistribusi normal. Berdasarkan uji Mann-Whitney N-Gain kemampuan pemecahan masalah pada tabel di atas nilai signifikansi o,ooo lebih kecil dari taraf signifikansi $(\alpha=0,05)$. Dengan demikian terdapat perbedaan yang signifikan N-Gain antara siswa kelas kontrol dan kelas eksperimen pada kemampuan pemecahan masalah.

Uji normalitas pretes berdasarkan kemampuan awal matematika yaitu uji normalitas berdasarkan kelompok siswa kategori tinggi, sedang dan rendah pada kelas kontrol dan kelas eksperimen. Kelompok siswa kategori tinggi kelas kontrol 0,00o kelas eksperimen o,001. Kelompok siswa kategori sedang kelas kontrol 0,001 kelas eksperimen 0,000. Kelompok siswa kategori rendah kelas kontrol 0,010 kelas eksperimen 0,000. Karena dari tiap kelompok siswa berdasarkan kemampuan awal, tinggi, sedang dan rendah baik pada kelas kontrol dan kelas eksperimen secara bersamaan tidak ada yang berdistribusi normal maka selanjutnya menggunakan uji nonparametrik yaitu uji Mann-Whitney.

Berdasarkan uji Mann-Whitney skor pretes untuk siswa kelompok tinggi mempunyai nilai signifikansi 0,735 lebih besar dari taraf signifikansi $(\alpha=0,05)$ sehingga tidak terdapat perbedaan yang signifikan skor 
pretes kelompok tinggi siswa kelas kontrol dan kelas eksperimen. Selanjutnya uji Mann-Whitney skor pretes untuk siswa kelompok sedang pada tabel di atas terlihat nilai signifikansi 0,128 lebih besar dari taraf signifikansi $(\alpha=0,05)$ sehingga demikian tidak terdapat perbedaan yang signifikan skor pretes siswa kelompok sedang kelas kontrol dan kelas eksperimen. Begitu pula uji Mann-Whitney skor pretes untuk siswa kelompok rendah pada tabel di atas terlihat nilai signifikansi o,186 lebih besar dari taraf signifikansi $(\alpha=0,05)$ sehingga tidak terdapat perbedaan yang signifikan skor pretes kelompok rendah siswa kelas kontrol dan kelas eksperimen.

Uji normalitas peningkatan N-gain berdasarkan kemampuan awal matematika yaitu berdasarkan kelompok siswa kategori tinggi, sedang dan rendah pada kelas kontrol dan kelas eksperimen. bahwa peningkatan N-Gain berdasarkan kemampuan awal matematika siswa kelompok tinggi pada kelas kontrol 0,021 lebih kecil dari taraf signifikansi 0,05 sehingga data tidak berdistribusi normal sedangkan kelompok tinggi pada kelas eksperimen 0,200 lebih besar dari taraf signifikansi 0,05 sehingga data berdistribusi normal. Jadi untuk menguji perbedaan rata-rata selanjutnya harus menggunakan uji Mann-Whithney. Sedangkan untuk data siswa kelompok sedang kelas kontrol 0,108 dan kelas eksperimen 0,200 kelompok rendah untuk kelas kontrol 0,144 dan kelas eksperimen o,200 masing-masing mempunyai nilai signifikansi lebih besar dari taraf signifikansi $\mathrm{O}, \mathrm{O} 5$ sehingga data berdistribusi normal selanjutnya harus dilakukan uji homogenitas.

Hasil uji homogenitas N-gain berdasarkan kemampuan awal matematika untuk siswa kelompok sedang mendapatkan nilai signifikansi o,667 dan kelompok rendah o,620. Karena masing-masing kelompok itu lebih dari taraf signifikansi 0,05 maka NGain berdasarkan kemampuan awal matematika untuk siswa kelompok sedang dan siswa kelompok rendah homogen.

Uji perbedaan rata-rata pada siswa kelompok tinggi menggunakan uji MannWhitney dan diperoleh nilai signifikansi o,001 karena nilai itu kurang dari taraf signifikansi 0,05 maka terdapat perbedaan peningkatan kemampuan pemecahan masalah matematis siswa kelompok tinggi antara kelas kontrol dan kelas eksperimen. Siswa kelompok sedang menggunakan uji-t diperoleh nilai signifikansi 0,214 karena nilai itu lebih dari taraf signifikansi 0,05 maka tidak terdapat perbedaan peningkatan kemampuan pemecahan masalah matematis siswa kelompok sedang antara siswa kelas kontrol dan kelas eksperimen. Demikian juga pada siswa kelompok rendah uji perbedaan rata-rata menggunakan uji-t dan diperoleh nilai signifikansi 0,081 karena nilai itu lebih dari taraf signifikansi 0,05 maka tidak terdapat perbedaan peningkatan kemampuan pemecahan masalah matematis siswa kelompok rendah antara siswa kelas kontrol dan kelas eksperimen.

Hasil peningkatkan pada kemampuan berpikir kreatif dan pemecahan masalah matematis ditunjang juga oleh angket skala sikap siswa terhadap pembelajaran pada materi aplikasi turunan. Secara umum siswa mempunyai sikap positif terhadap pembelajaran dengan model investigasi kelompok terlihat pada perolehan rata-rata skor 3,04 dari netral 2,50. Siswa begitu merasakan manfaat belajar matematika dengan cara yang baru dan mereka dituntut aktif terlibat dalam pembelajaran. Namun 
Meningkatkan Kemampuan Berpikir Kreatif dan Pemecahan Masalah Matematis Siswa Madrasah Aliyah

keaktifan siswa dalam kelompok belum merata, sebagian kecil siswa masih kurang inisiatif.

\section{KESIMPULAN}

Dapat ditarik kesimpulan bahwa kemampuan berpikir kreatif siswa yang menggunakan pembelajaran biasa maupun model investigasi kelompok mengalami peningkatan. Rata-rata peningkatan kemampuan berpikir kreatif dengan menggunakan pembelajaran biasa tergolong rendah sedangkan pembelajaran menggunakan model investigasi kelompok tergolong cukup. Terdapat perbedaan peningkatan (N-Gain) kemampuan berpikir kreatif antara siswa yang mendapat pembelajaran biasa dan siswa yang mendapat pembelajaran dengan model investigasi grup.

Kemampuan berikir kreatif berdasarkan kemampuan awal matematika siswa kelompok tinggi, sedang dan rendah yang mendapat pembelajaran biasa dan model grup investigasi mengalami peningkatan (N-Gain). Terdapat perbedaan peningkatan (N-Gain) berdasarkan kemampuan awal matematika antara kelompok siswa tinggi, sedang dan rendah yang mendapatkan pembelajaran biasa dan pembelajaran model investigasi kelompok. Kelompok siswa tinggi dan sedang pada kelas kontrol peningkatannya sedang pada kelas eksperimen peningkatannya juga sedang. Siswa kelompok rendah pada kelas kontrol peningkatannya rendah pada kelas eksperimen peningkatannya sedang.

Pada kemampuan pemecahan masalah baik yang menggunakan pembelajaran biasa maupun menggunakan model investigasi kelompok mengalami peningkatan. Rata-rata peningkatan kemampuan pemecahan masalah matematis siswa dengan pembelajaran biasa tergolong rendah sedangkan dengan pembelajaran menggunakan model investigasi kelompok tergolong sedang. Terdapat perbedaan peningkatan kemampuan pemecahan masalah antara siswa yang mendapat pembelajaran biasa dan siswa yang mendapat pembelajaran dengan model investigasi kelompok.

Kemampuan pemecahan masalah matematis berdasarkan kemampuan awal matematika siswa kelompok tinggi, sedang dan rendah yang mendapatkan pembelajaran biasa dan yang mendapatkan pembelajaran model investigasi kelompok mengalami peningkatan (N-Gain). Terdapat perbedaan peningkatan (N-Gain) siswa kelompok tinggi, pada kelas kontrol dan eksperimen, sedangkan untuk kelompok sedang dan rendah pada kelas kontrol dan eksperimen tidak terdapat perbedaan peningkatan $(\mathrm{N}-$ Gain). Rata-rata peningkatan (N-Gain) pada siswa kelompok tinggi, sedang dan rendah pada kelas kontrol tergolong rendah sedangkan siswa kelompok tinggi, sedang dan rendah pada kelas eksperimen tergolong sedang.

Hendaknya peneliti lain mencoba model pembelajaran investigasi kelompok dibandingkan dengan berbagai pembelajaran lain. Atau dapat juga diteliti, bagaimana pembelajaran ini jika menggunakan aspek kemampuan yang lain. Hasil penelitian ini berupa pembelajaran dengan model investigasi kelompok dapat digunakan sebagai alternatif pembelajaran matematika, sekalipun dipakai pada materi yang lain.

Diharapkan pembuat kebijakan mensosialisasikan hasil-hasil penelitian pendidikan termasuk penggunaan metode, pendekatan ini kepada guru-guru di lapangan. Sehingga guru-guru dapat memanfaatkan berbagai hasil penelitian, termasuk penelitian tentang model investigasi kelompok ini.

\section{DAFTAR PUSTAKA}

Armanto, D. (2009). Matematika bukan Pelajaran Menakutkan. [Senin 27 Juli 2009] Waspada Medan[Online].[05 Pebruari 2012]

Haji, S. (2004). Pengaruh Pendekatan Matematika Realistik terhadap Hasil Belajar Matematika di Sekolah Dasar. Disertasi. Bandung: Program Pascasarjana UPI.

Harris, R. (2000). Criteria for Evaluating a Creative Solution. [Online]. Tersedia: 
Wawan Kusmawan, Turmudi, Dadang Juandi dan Hamdan Sugilar

http://www.virtualsalt.com/creative.htm. [2 Januari 2012]

Herman, T. Matematika dan Pembelajaran Matematika di Sekolah Dasar. Makalah. Bandung: UPI

Hobri, \& Susanto. (2006). Penerapan Pendekatan Cooperative Learning Model Grup Investigasi untuk Meningkatkan Pemahaman Siswa Kelas III SLTPN 8 Jember tentang Volume Tabung. Jurnal Pendidikan Dasar. Vol.7 No.2 Jember: FKIP Universitas Jember.

Izzati, N. (2009). Berpikir Kreatif dan Kemampuan Pemecahan Masalah Matematis: Apa, Mengapa, dan Bagaimana Mengembangkannya Pada Peserta Didik. Makalah pada Seminar Nasional Matematika. Bandung 19 Desember 2009,

Joyce, B., Weil M, \& Calhoun, E.(2000). Model of Teaching. Sydney: Allyn \& Bacon

Ngurah Japa, I.G. (2008). Peningkatan Kemampuan Pemecah dan Masalah Matematika Terbuka melalui Investigasi bagi Siswa Kelas V SD Kaliuntu, Jurnal. Singaraja: Undiksha.

Novaliyosi. (2006). Meningkatkan Kemampuan Berpikir Kritis Matematis dan Kemandirian Belajar Mahasiswa Melalui Pembelajaran dengan Pendekatan Investigasi. Tesis. Bandung: Program Pasacasarjana UPI.

Ruseffendi, E.T. (2001), Statistika Dasar untuk Penelitian Pendidikan, untuk perkuliahan Proyek pembinaan Tenaga Kependidikan Pendidikan Tinggi.

Sabandar, J. (2009). Belajar Matematika Meningkatkan Berpikir Kreatif. [Senin 27 Juli 2009] Waspada[Online] Medan [05 Pebruari 2012]
Setiawan. (2006). Model Pembelajaran Matematika dengan Menggunakan Investigasi. Jogjakarta, $\mathrm{P}_{3} \mathrm{G}$ Matematika.

Sugilar, H. (2013). Meningkatkan Kemampuan Berpikir Kreatif Dan Disposisi Matematik Siswa Madrasah Tsanawiyah Melalui Pembelajaran Generatif. Jurnal Ilmiah Program Studi Matematika STKIP Siliwangi Bandung, Vol 2, No.2, September 2013157

Sumarmo, U. (1993). Peranan Kemampuan Logik dan Kegiatan Belajar terhadap Kemampuan Pemecahan Masalah Matematik pada Siswa SMA di Kodya Bandung. Laporan Penelitian IKIP Bandung: tidak diterbitkan.

Susilawati, E, dkk. (2017). Pendekatan Eksplorasi Berbasis Intuisi Pada Kemampuan Pemecahan Masalah Matematis. Jurnal Analisa Vol.3 No.2 Desember 2017 :138-147

Syaban, M. (2008). Menumbuhkembangkan Daya dan Disposisi Matematis siswa Sekolah Menengah Atas melalui Pembelajaran Investigasi. Disertasi. Bandung. Program Pascasarjana UPI.

Turmudi. (2009). Pemecahan Masalah Matematika, Makalah. Disampaikan dalam Pengembangan Pendidikan Guru MI Arraniri Banda Aceh.

Wahyudin. (1999). Kemampuan Guru Matematika, Calon Guru Matematika, dan Siswa dalam Mata Pelajaran Matematika. Disertasi Bandung: PPS UPI: tidak diterbitkan. 